\title{
PENGARUH KOMPENSASI DAN MOTIVASI TERHADAP KINERJA KARYAWAN DENGAN KEPUASAN KARYAWAN SEBAGAI VARIABEL INTERVENING PADA PT BANK NEGARA INDONESIA CABANG BATAM
}

\author{
Heryenzus $^{1}$, Restui Laia ${ }^{2}$ \\ ${ }^{1}$ Universitas Putera Batam \\ heryenzuss@gmail.com
}

\begin{abstract}
This study aims to determine the effect of compensation, motivation, compensation on employee performance, employee performance motivation and to determine the effect of job satisfaction on employee performance at PT. Bank Negara Indonesi Batam Branch. This study uses saturated samples for all employees at PT. Bank Negara Indonesi Batam Branch. Analysis method of this research using path analysis. Based on the results of the analysis found that compensation has a positive effect on job satisfaction, motivation has a positive and significant effect on job satisfaction, compensation has a positive and significant impact on employee performance, motivation has a positive and significant impact on employee performance, job satisfaction has a positive and significant influence on performance and employee satisfaction. Working mediates the effect of compensation and motivation on employee performance. Based on research results, PT. Bank Negara Indonesi Batam Branch. Should be fair compensation, motivate employees with promotion.
\end{abstract}

Keywords: Compensation, Motivation, Employee Performance, Job Satisfaction

\begin{abstract}
ABSTRAK
Penelitian ini bertujuan untuk mengetahui pengaruh kompensasi, motivasi, kepuasan terhadap kinerja karyawan, motivasi kinerja karyawan dan untuk mengetahui pengaruh kepuasan kerja terhadap kinerja karyawan pada PT. Bank Negara Indonesi Cabang Batam. Penelitian ini menggunakan sampel jenuh untuk seluruh karyawan di PT. Bank Negara Indonesi Cabang Batam. Metode analisis penelitian ini menggunakan analisis jalur. Berdasarkan hasil analisis ditemukan bahwa kompensasi memiliki pengaruh positif terhadap kepuasan kerja, motivasi mempunyai pengaruh positif dan signifikan terhadap kepuasan kerja, kompensasi berpengaruh positif dan signifikan terhadap kinerja karyawan, motivasi berpengaruh positif dan signifikan terhadap kinerja karyawan, pekerjaan kepuasan memiliki pengaruh positif dan signifikan terhadap kinerja dan kepuasan karyawan. Bekerja memediasi pengaruh kompensasi dan motivasi terhadap kinerja karyawan. Berdasarkan hasil penelitian, PT. Bank Negara Indonesi Cabang Batam. Seharusnya kompensasi yang adil, memotivasi karyawan dengan promosi.
\end{abstract}

Kata Kunci: kompensasi, motivasi, kepuasan, kinerja

\section{PENDAHULUAN}

Suatu organisasi atau perbankan akan mengalami perubahan, yang mengarah pada kemajuan dan perkembangan menuju yang lebih baik. Setiap perbankan akan berusaha meningkatkan dan mengembangkan perbankan dengan mengadakan berbagai kegiatan guna meningkatkan kinerja para karyawan. Dalam meningkatkan kinerja karyawannya pihak manajemen perbankan akan melakukan beberapa cara yang dapat mendorong karyawan untuk bekerja secara maksimal. Beberapa kegiatan tersebut diantaranya pemberian pelatihan, pemberian kompensasi, pemberian penghargaan, motivasi dan lain sebagainya. Manajemen kinerja merupakan suatu proses yang dirancang untuk menghubungkan tujuan organisasi dengan tujuan individu sehingga kedua tujuan tersebut bertemu. Dengan demikian, kinerja adalah tentang melakukan pekerjaan dan hasil yang dicapai dari pekerjaan tersebut dan tentang apa yang harus dikerjakan dan bagaimana cara mengerjakannya.

Karyawan Bank BNI Cabang Batam merupakan salah satu aset yang memegang peranan penting dalam keberhasilan Bank BNI menjadi Lembaga Keuangan. Karena dengan karyawan tersebut kegiatan perusahaan dapat terlaksana dengan baik, karena itu kinerjanya dituntut lebih profesional guna dapat meningkatkan produktivitasnya dalam bekerja. Bank BNI 
cabang Batam yang beralokasi di Jalan. Imam Bonjol Lubuk Baja Kota, Lubuk Baja, Kota Batam. Dalam aktivitas kerjanya berusaha untuk selalu menekankan kepada seluruh sumber daya manusiannya untuk dapat mencapai kinerja yang baik, dimana manfaat dari kinerja tersebut tidak hanya dirasakan dari individu tetapi juga dirasakan oleh institusi yang bersangkutan. Berdasarkan penilaian kinerja karyawan pada PT Bank Negara Indonesia (Persero) Tbk pada tahun 2015 kinerja karyawan bisa dikatakan sangan meningkat pertumbuhan kinerja karyawan, ketika pada tahun 2016 karyawan bertambah 3 orang dan penilaian kinerja menurun berdasarkan penilaian kinerja pada PT Bank Negara Indonesia (Persero) Tbk Cabang Batam.

Berdasarkan observasi awal diperoleh informasi telah terjadinya penurunan disiplin karyawan. Hal ini terlihat dari data absensi dan keterlambatan karyawan Bank BNI Cabang Batam, tingkat absensi karyawan selama tahun 2016 mempunyai rata-rata sebesar 1,02\% lebih besar dari tingkat tolerir absensi yang ditetapkan BNI pusat yaitu sebesar $1 \%$, permasalahan ini harus mendapatkan perhatian yang sungguhsungguh dari manajemen BNI (Persero) Tbk Cabang Batam, untuk mengatasi persoalan yang terungkap. Berikut data program yang memperlihatkan program kerja yang berhubungan dengan kinerja karyawan pada BNI (Persero) Tbk Cabang Batam dan pelaksanaanya di tahun 2016, terlihat bahwa dari dua rencana kerja yang ada yaitu Penagihan piutang nasabah yang mengalami penunggakan, dan menambah jumlah nasabah yang baru pada tahun 2016, tidak adanya realisasi yang dicapai oleh perusahaan data tersebut memperlihatkan bahwa kinerja karyawan pada BNI Cabang Batam belum terlaksana dengan baik.

Hal ini menunjukan bahwa BNI (Persero) Tbk Cabang Batam memerlukan good management artinya harus mengembangkan Sumber Daya Manusia sebagai good manager dan organisasi yang baik, maka untuk meningkatkan kinerja perusahaan sangat dipengaruhi oleh kemampuan seorang pemimpin dalam menggerakkan bawahannya untuk bekerja sama dalam melaksanakan tugasnya secara efektif dan efisien.

\section{TINJAUAN PUSTAKA}

Menurut Rachmawati (2008 : 144), kompensasi merupakan segala sesuatu yang di terima oleh karyawan sebagai balas jasa untuk kerja mereka, dan salah satu cara organisasi untuk meningkatkan prestasi kerja, motivasi, dan kepuasan kerja kepada karyawan. Dalam kepegawaian, hadiah yang bersifat uang merupakan kompensasi yang diberikan kepada pegawai sebagai penghargaan dari pelayanan mereka. Dengan demikian, apabila karyawan memandang bahwa bila kompensasi tidak memadai maka prosuktivitas, prestasi kerja, dan kepuasan kerja akan turun. Menurut Hanggraeni (2012 : 139) kompensasi atau compensation adalah segala sesuatu yang diterima oleh karyawan sebagai balas jasa yang diberikan yang diberikan oleh organisasi atau pekerjaan yg dilakukannya. Kompensasi ini harus dikelolah secara serius dan tepat oleh perusahaan. Apabila tidak dikelolah dengan baik bisa mengakibatkan pay dissatifation yaitu perasaan ketidakpuasan karyawan atas balas jasa yang diterimanya.

Komponen dari keseluruhan program gaji secara umum dikelompokkan kedalam kompensasi finansial langsung, tak langsung dan non finansial.

1. Kompensasi finansial secara langsung berupa; bayaran pokok (gaji dan upah), bayaran prestasi, bayaran insentif (bonus, komisi, pembagian laba/keuntungan dan opsi saham) dan bayaran tertangguh (program tabungan dan anuitas pembelian saham)

2. Kompensasi finansial tidak langsung berupa; program-program proteksi (asuransi kesehatan, asuransi jiwa, pensiun, asuransi tenaga kerja), bayaran diluar jam kerja (liburan, hari besar, cuti tahunan dan cuti hamil) dan fasilitas-fasilitas seperti kendaran,ruang kantor dan tempat parkir.

3. Kompensasi non financial, berupa pekerjaan (tugas-tugas yang menarik, tantangan, tanggung jawab, pengakuan dan rasa pencapaian). Lingkungan kerja (kebijakan-kebijakan yang sehat, supervise yang kompoten, kerabat yang menyenangkan, lingkungan kerja yang nyaman).

Setiap perusahaan memiliki indikator yang berbeda-beda dalam proses pemberian kompensasi untuk karyawan. Menurut Hasibuan (2012 : 86) mengemukakan, secara 
umum ada beberapa indikator kompensasi yaitu :

1.Gaji

Balas jasa daalam bentuk uang yang diterima karyawan sebagai konsekuensi dari kedudukan sebagai seorng karyawan yang member sumbangan tenaga dan pikiran dalam memapai tujuan perusahaan

2.Upah

Imblan financial lngsung yang d ibyaarkan kepada karyawan berdasarkaan jam kerja, jumlah barang yang dihasilkan atau banyak pelayanan yang diberikaan.

3.Insentif

Imbalan langsung yang dibayarkan kepada kaaryawannya karena kinerjanya melebihi standar yang ditentukan.

4. Tunjangan

Dapaat berupa menghimpun potongan gaji, kombinasi adangan dana perusaahaaan, menghubungkan dana pension dengn asuransi, dan pembayaran dapat dilakukan dengan ara bulanan, dibayarkan sekaligus ata kombinasi diantara keduanya.

Menurut Wibowo (2007 : 349), tujuan manjemen kompensasi adalah membantu organisasi mencapai keberhasilan strategis sambil memastikan keadilan internal dan eksternal. Internal equity atau keadilan internal memastikan bahwa jabatan yang lebih menantang atau orang yang mempunyai kualifikasi lebih baik dalam organisasi dibayar lebih tinggi. External equity atau keadilan eksternal manajemen bahwa pekerjaan mendapatkan kompensasi secara adil dalam perbandingan dengan pekerjaan yang sama di pasar tenaga kerja.

Menurut Notoatmodjo (2009 : 114) Motif atau motivasi berasal dari kata latin "moreve" yang berarti dorongan dari dalam diri manusia untuk bertindak atau berperilaku. Pengertian motivasi tidak terlepas dari kata kebutuhan atau "needs" atau "want". Kebutuhan adalah suatu potensi dalam diri manusia yang perlu ditanggapi ataun direspon. Pada dasarnya motivasi akan muncul ketika ada dorongan untuk berperilaku dan bertindak. Biasanya hal ini sering kali dihubungkan dengan kebutuhan dan keinginan manusia. Sebagaimana yang dikemukakan oleh Kadarisman (2012: 273) bahwa "the motivation of people depends on the strength of their motives. Motives are sometimes define as needs, wants, or impulses within the individual". Kebutuhan atau keinginan pegawai pada dasarnya berbeda - beda, untuk itu perusahaan perlu melakukan survey untuk mengetahui keinginan dan kebutuhan pegawainya dalam rangka menciptakan motivasi kerja.

Menurut Sutrisno (2011: 116) motivasi sebagai proses psikologi dalam diri seseorang yang akan dipengaruhi oleh beberapa faktor. Faktor - faktor tersebut dapat dibedakan atas faktor intern dan faktor ekstren yang berasal dari karyawan:

1. Faktor intern

Faktor intern yang dapat mempengaruhi pemberian motivasi pada seseorang antara lain:

a. Keinginan untuk dapat hidup

Untuk mempertahankan hidup, orang mau mengerjakan apa saja, apakah pekerjaan itu baik atau tidaknya, apakah halal atau haram, dan sebagainya.

b. Keinginan untuk dapat memiliki

Keinginan untuk memiliki benda dapat mendorong seseorang untuk mau melakukan pekerjaan.

c. Keinginan untuk memperoleh penghargaan

Seseorang mau bekerja disebabkan adanya keinginan untuk diakui dan dihormati oranglain.

d. Keinginan untuk memperoleh pengakuan

e. Keinginan untuk berkuasa

Keinginan untuk berkuasa akan mendorong seseorang untuk bekerja

2. Faktor ekstren

Faktor ekstren juga tidak kalah peranannya dalam melemahkan motivasi kerja seseorang. Faktor - faktor ekstren tersebut adalah :

a. Kondisi lingkungan kerja

Lingkungan kerja adalah keseluruhan sarana dan prasarana yang ada disekitar karyawan yang sedang melakukan pekerjaan yang dpat mempengaruhi pelaksanaaan pekerjaan.

b. Kompensasi yang memadai

Kompensasi yang memadai merupakan alat motivasi yang paling ampuh bagi perusahaan untuk mendorong para karyawan bekerja dengan baik.

c. Adanya jaminan pekerjaan

Setiap orang akan mau bekerja mati matian kalau yang bersangkutan merasa 
ada jaminan karir yang jelas dalam melakukan pekerjaan,

d. Supervise yang baik

Peranan supervisor yang melakukan pekerjaan supervise sangat mempengaruhi motivasi kerja karyawan.

Indikator - indikator yang digunakan untuk mengukur motivasi menurut Sanusi (2012: 68) adalah sebagai berikut:

1. Kebutuhan fisiologis (physiological needs), adalah kebutuhan dasar untuk mempertahankan hidup seperti kebutuhan makan minum, tempat tinggal, bebas dari sakit.

2. Kebutuhan keamanan dan rasa aman (safety and security needs), adalah kebutuhan akan kebebasan dari ancaman dan terjaminnya keselamatan yang meliputi keselamatan dan perlindungan terhadap kerugian fisik dan emosional.

3. Kebutuhan sosial (social needs), adalah kebutuhan yang meliputi akan kasih saying, rasa memiliki, diterima baik, dan persahabatan.

4. Kebutuhan harga diri ( esteem needs), meliputi kebutuhan akan harga diri dan penghargaan dari orang lain seperti pengakuan akan prestasi, harga diri, dan perhatian.

5. Kebutuhan aktualisasi diri (self actualization), meliputi tercapainya potensi diri dan pemenuhan diri.

Tujuan pemberian motivasi antara lain mendorong gairah dan semangat kerja karyawan, meningkatkan morah dan kepuasan kerja karyawan, meningkatkan produktivitas kerja karyawan, mempertahankan loyalitas dan kestabilan karyawan perusahaan, meningkatkan kedisiplinan dan menurunkan tingkat absensi, menciptakan suasana dan hubungan kerja yang baik, meningkatkan kreatifitas dan partisipasi karyawan, meningkatkan kesejahteraan karyawan, mempertinggi rasa tanggung jawab terhadap tugas - tugasnya (Sunyoto, 2012: 98).

Menurut Sedamayanti(2011: 206) kinerja karyawan adalah sebuah hasil kerja yang telah dicapai oleh pegawai atau karyawan yang sesuai dengan kriteria maupun standar yang sebelumnya telah ditetapkan pada periode tertentu.Kinerja adalah hasil yang diperoleh oleh suatu organisasi baik organisasi yang kersifat profit oriented maupun non profit oriented yang dihasilkan selama satu periode waktu (Irham dan Fahmi, 2013 : 226). Kesediaan dan ketrampilan seseorang tidaklah cukup efektif untuk mengerjakan sesuatu tanpa pemahanan yang jelas tentang apa yang dikerjakan dan bagaimana mengerjakannya. Kinerja merupakan perilaku nyata yang ditampilkan setiap orang sebagai prestasi kerja yang dihasilkan oleh karyawan sesuatu dengan perannya dalam perusahaan Yani (2012:117). Faktor-faktor penentu pencapaian prestasi kinerja atau kinerja individu dalam organisasi menurut Anwar Prabu Mangkunegara (2006: 18) adalah sebagai berikut :

1. Faktor Individu

Secara psikologis, individu yang normal dalah individu yang memiliki integritas yang tinggi antara fungsi psikis (rohani) dan fisiknya (jasmaniah).Dengan adanya integritas yang tinggi antara fungsi psikis dan fisik, maka individu tersebut memiliki konsentrasi diri yang baik.Konsentrasi yang baik ini merupakan modal utama individu manusia untuk mampu mengelola dan mendayagunakan potensi dirinya secara optimal dalam melaksanakan kegiatan atau aktifitas kerja sehari-hari dalam mencapai tujuan organisasi.

2. Faktor Lingkungan Organisasi

Faktor lingkungan organisasi sangat menunjang bagi individu dalam mencapai prestasi kerja. Faktor-faktor lingkungan organisasi yang baik antara lain uraian jabatan yang jelas, autoritas yang memadai, target kerja yang menantang, pola komunikasi yang efektif, hubungan kerja harmonis, iklim kerja respek dan dinamis, peluang berkarier dan fasilitas kerja yang relative memadai.

Menurut Abdullah (2014: 152) indikator untuk mengukur kinerja karyawan secarfa individu ada enam yaitu :

\section{Efektif}

Indikator ini mengukur derajat kesesuaian yang dihasilkan dalam mencapai sesuatu yang di inginkan. Indicator efektivitas ini menjawab pertanyaan mengenai apakah kita melakukan sesuatu yang sudah benar.

2. Efisien

Indikator ini mengukur derajat kesesuaian proses menghasilkan output dengan menggunakan biaya serendah mungkin. 
Indicator efektivitas seperti ini menjawab pertanyaan mengenai apakah kita akan melakukan sesuatu dengan benar.

3. Kualitas

Indikator ini mengukur derajat kesesuaian antara kualitas produk atau jasa yang dihasilkan dengan kebutuhan dan harapan konsumen.

4. Ketepatan waktu

Indikator ini mengukurapakah pekerjaan telah diselesaikan secara benar dan tepat waktu.

5. Produktivitas

Mengukur tingkat efektivitas suatu organisasi

6. Keselamatan Kerja

Indikator ini mengukur kesehatan organisasi secara keseluruhan serta lingkungan kerja para karyawan ditinjau dari aspek kesehatan.

Penilaian yang dilakukan secara adil dapat meningkatkan kinerja karyawan. Karyawan yang kurang berprestasi biasanya mendapatkan teguran atau himbauan, dengan begitu diharapkan dapat meningkatkan kinerjanya. Dengan demikian pihak atasan harus dapat memberikan penilaian terhadap kinerja karyawannya dengan lebih berhatihati.

Menurut Serdamayanti (2011: 126) beberapa faktor yang mungkin menjadi hambatan dalam penilaian kinerja karyawannya adalah sebagai berikut :

1. Perubahan standar

Perubahan yang tidak konsisten dan berubah-ubah akan mempengaruhi penilaian kinerja karyawan.

2. Perbedaan sifat manajer

Manajer mempunyai sifat dan karakter yang berbeda-beda.Penilaian manajer, olehkinerja karyawan bisa menjadi berbeda Karena sifat manajer, oleh karena itu disarankan untuk membuat starndar penilaian untuk menjadi patokan agar penilaian dapat dilakukan secara adil.

3. Perbedaan stereotype tertentu

Manajer dapat menjadi bias karena faktor entis, jenis kelamin, atau golongan tertentu. Untuk menghindari hal tersebut manajer harus berpegang pada pedoman atau standar tertulis dan hasil penelitian prestasi pun harus dilakukan secara tertulis agar dapat dipertanggung jawabkan.

Kata kepuasan atau satisfaction berasal dari bahasa latin "satis" (artinya cukup baik, memadai dan melakukan atau membuat. Secara sederhana kepuasan dapat diartikan sebagai upaya pemenuhan sesuatu atau membuat memadai (Tjiptono 2008 : 58). Menurut Rivai dan Sagala (2011 : 856) menyatakan bahwa kebutuhn manuisia sangat6 beranekaragam,baik jeni maupun tingkt, manuia memiliki kebutuhan yang enderung tak terbatas. Artinya, kebutuhan elalu bertambah dari waktu kewaktu dan manuia elalu beruaha egala kemampuannya untuk memuaskan kebutuhan tersebut. Kebutuhan manusia diartikan sebagai segala sesuatu yang ingin dimilikinya, dicapai dan dinikmati. Banyak ahli yang memberikan pendapatnya mengenai faktor faktor yang mempengaruhi kepuasan kerja.

\section{METODE}

Menurut Sangadji dan Sopiah (2010: 288) desain penelitian adalah rancangan utama penelitian yang menyatakan metode- metode dan prosedur- prosedur yang digunakan oleh peneliti dalam pemilihan, pengumpulan, dan analisis data. Desain penelitian yang digunakan dalam penelitian ini mulai dari kerangka berfikir dan penyusunan hipotesa sampai pada kesimpulan dan saran. Penelitian ini menggunakan teknik analisis data yaitu analisis jalur (path analysis). Dalam Buku Metode Penelitian Kuantitatif Kualitatif dan R\&D, Menurut Sugiyono (2012: 38) menyimpulkan bahwa variabel penelitian adalah sesuatu yang berbentuk apa saja yang ditetapkan oleh peneliti untuk dipelajari sehingga diperoleh informasi tentang hal tersebut dan ditarik kesimpulan.

Populasi dalam penelitian berjumlah 116 orang yang merupakan seluruh karyawan pada PT Bank Negara Indonesia. Penelitian ini menggunakan sampel jenuh dengan menggunakan seluruh karyawan. Menurut Sanusi (2011: 87)

Dalam penelitian ini melihat jumlah populasi yang relatif kecil yaitu 116 responden dan untuk mendapatkan tingkat kesalahan dalam penelitian yang lebih kecil, maka dalam teknik sampling peneliti menggunakan teknik non probability sampling dengan sampling jenuh. Sugiyono (2012: 85) sampling jenuh adalah teknik penentuan sampel bila semua anggota populasi digunakan sebagai sampel. Untuk itu 
sampel penelitian ini mengambil keseluruhan populasi yaitu 116 orang.

\section{HASIL PENELITIAN DAN PEMBAHASAN}

Dalam penelitian ini telah disebarkan sebanyak 116 kuesioner.Dimana responden penelitian ini adalah para karyawan atau staf yang bekerja pada PT Bank Negara Indonesia (Persero) Tbk Cabang Batam. Karakteristik yang dibahas dalam penelitian ini meliputi jenis kelamin, status, usia dan pendidikan. Reponden tersebut diolah menggunakan SPSS versi 20 untuk mendapatkan persentase karakteristik responden. Penyajian data mengenai identitas responden untuk memberikan gambaran tentang keadaan diri dari para responden. Dalam mengisi kuesioner, responden diminta memberikan identitas diri sebagai penunjang data.

\section{Uji Validitas Data}

Pengujian untuk membuktikan valid tidaknya item-item kuesioner dapat dilakukan dengan melihat angka koefisien korelasi product moment pearson. Dalam menentukan kelayakan suatu item yang digunakan biasanya dilakukan uji signifikasi koefisien korelasi pada tingkat 0,05 (Wibowo, 2012:37).

Uji Validitas Variabel Kompensasi (X1)

Tabel 1. Hasil Uji Validitas Variabel Kompensasi kerja (X1)

\begin{tabular}{cccc}
\hline Pernyataan & r hitung $(>)$ & r tabel & Keterangan \\
\hline X1_1 & 0,719 & 0,189 & Valid \\
X1_2 & 0,695 & 0,189 & Valid \\
X1_3 & 0,617 & 0,189 & Valid \\
X1_4 & 0,734 & 0,189 & Valid \\
\hline
\end{tabular}

Uji Validitas Variabel Motivasi Kerja (X2)

Tabel 2. Hasil Uji Validitas Variabel motivasi kerja (X2)

\begin{tabular}{rrrr}
\hline Pernyataan & r hitung & \multicolumn{1}{c}{ r tabel } & \multicolumn{1}{c}{ Keterangan } \\
\hline X2_1 & 0,611 & 0.189 & Valid \\
X2_2 & 0,746 & 0.189 & Valid \\
X2_3 & 0,600 & 0.189 & Valid \\
X2_4 & 0,758 & 0.189 & Valid \\
X2_5 & 0,727 & 0.189 & Valid \\
\hline
\end{tabular}

Uji Validitas Variabel Kinerja karyawan (Y1)

Tabel 3. Hasil Uji Validitas Variabel Kinerja Karyawan (Y1)

\begin{tabular}{cllc}
\hline Pernyataan & r hitung & r tabel & Keterangan \\
\hline Y1_1 & 0,729 & 0.189 & Valid \\
Y1_2 & 0,659 & 0.189 & Valid \\
Y1_3 & 0,678 & 0.189 & Valid \\
Y1_4 & 0,727 & 0.189 & Valid \\
Y1_5 & 0,624 & 0.189 & Valid \\
Y1_6 & 0,639 & 0.189 & Valid \\
\hline
\end{tabular}

Uji Validitas Variabel Kepuasan Kerja (Y2)

Tabel 4.. Hasil Uji Validitas Variabel Kepuasan Kerja (Y2) 


\begin{tabular}{cccc}
\hline Pernyataan & r hitung & r tabel & Keterangan \\
\hline Y2_1 & 0,889 & 0.179 & Valid \\
Y2_2 & 0,886 & 0.179 & Valid \\
Y2_3 & 0,296 & 0.179 & Valid \\
Y2_4 & 0,849 & 0.179 & Valid \\
Y2_5 & 0,843 & 0.179 & Valid \\
\hline
\end{tabular}

Uji Kolmogorov-Smirnov

Tabel 5. Hasil Uji Kolmogorov-Smirnov

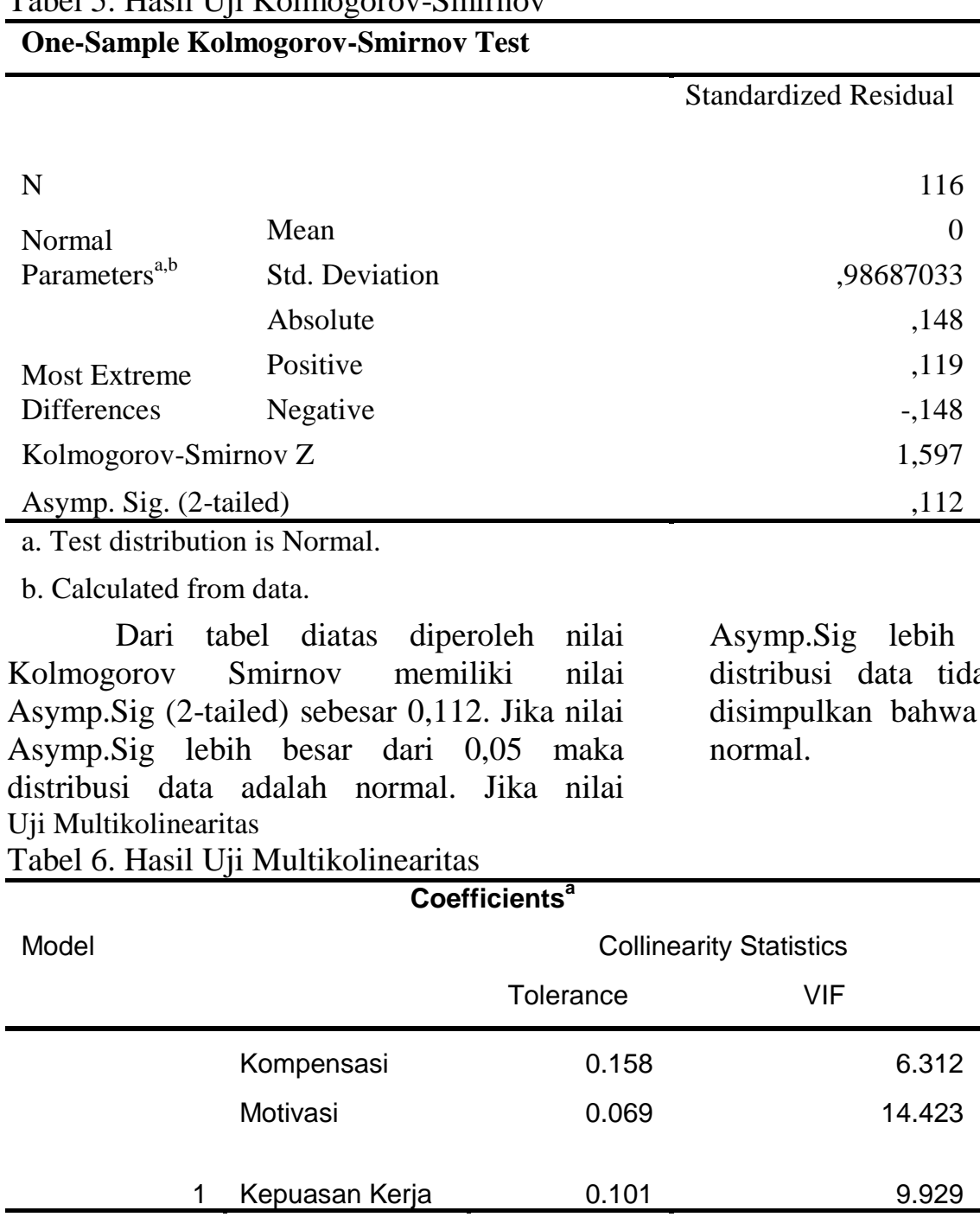

a. Dependent Variable: Kinerja Karyawan

Berdasarkan tabel diatas, dapat diketahiu bahwa nilai VIF untuk variabel kompensasi adalah sebesar 6.312, motivas 14,423, dan kepuasan kerja sebesar 9,929 lebih kecil dari 10. Dengan demikian dapat disimpulkan dalam model ini tidak terdapat gejala multikolinearitas antar variabel independen.

\section{Analisis Jalur (Path Analysis)}

Analisis jalur ini digunakan dalam menguji besarnya sumbangan yang ditunjukana oleh koefisien jalur pada setiap diagram jalur dari hubungan kausal antara variabel $\mathrm{X} 1, \mathrm{X} 2$ terhadap $\mathrm{Y} 1$ dan dan dampaknya kepada Y2 (Ridwan dan kuncoro 2012 : 115). Langkah pertama dalam analisis 
jalur adalah membuktikan bahwa ada pengaruh variabel bebas kompensasi (X1) dan motivasi (X2) terhadap variabel dependen kepuasan kerja (Y1). Hasil analisis untuk mengetahui pengaruh variabel Tabel 7 . Hasil Analisis Jalur Persamaan Struktual 1 komepnsasi (X1 dan motivasi (X2) terhadap kepuasan kerja (Y2), dalam tabel 2 Hasil Analisis Jalur Persamaan Struktual 1.

Coefficients $^{\mathrm{a}}$

Model

Unstandardized Coefficients

Standardized

$\mathrm{t}$

Sig.

B

Std. Error

Beta

\begin{tabular}{rlllrr}
\hline (Constant) & 1.698 & 0.756 & & 2.247 & 0.027 \\
Kompensasi & 0.068 & 0.108 & 0.147 & 0.627 & 0.532 \\
$1 \quad$ Motivasi & 1.065 & 0.088 & 0.905 & 12.087 & 0 \\
a. Dependent Variable: Kepuasan Kerja & & & &
\end{tabular}

Nilai error term (e) sebesar 0,948, dimana memiliki arti kepuasan kerja yang dipengaruhi oleh faktor luar dari kompensasi dan motivasi sebesar 89,9 persen. Oleh karena Standardized Coefficients Beta $=0,147$ dan Sigt $=0,027<0,05$ maka dapat disimpulkan kompensasi berpengaruh positif terhadap kepuasan kerja. Oleh karena Standardized Coefficients Beta $=0,905$ dan Sigt $=0,000<$
0,05 maka maka kesimpulannya adalah Ho ditolak dan Ha diterima

Langkah kedua dalam analisis jalur adalah membuktikan bahwa ada pengaruh variabel bebas kompensasi X1, motivasi X2 dan kepuasan kerja Y1 terhadap variabel dependen kinerja karyawan Y2. Hasil analisis untuk mengetahui pengaruh variabel kompensasi X1, motivasi X2 dan kepuasan kerja Y1 terhadap variabel dependen kinerja karyawan Y2. Hasil analisis jalur persamaan Struktural 2.

Tabel 8. Hasil Analisis Jalur Persamaan Struktual II

\begin{tabular}{|c|c|c|c|c|c|c|}
\hline \multicolumn{7}{|c|}{ Coefficients $^{\mathrm{a}}$} \\
\hline \multirow[t]{2}{*}{ Model } & & \multicolumn{2}{|c|}{ Unstandardized Coefficients } & \multirow{2}{*}{$\begin{array}{c}\text { Standardized } \\
\text { Coefficients } \\
\text { Beta }\end{array}$} & \multirow[t]{2}{*}{$\mathrm{T}$} & \multirow[t]{2}{*}{ Sig. } \\
\hline & & B & Std. Error & & & \\
\hline & (Constant) & 0.63 & 0.863 & & 0.73 & 0.467 \\
\hline & Kompensasi & 0.24 & 0.121 & 0.178 & 1.988 & 0.049 \\
\hline & Motivasi & 1.555 & 0.149 & 1.409 & 10.431 & 0 \\
\hline 1 & $\begin{array}{l}\text { Kepuasan } \\
\text { Kerja }\end{array}$ & 0.326 & 0.105 & 0.348 & 3.104 & 0.002 \\
\hline
\end{tabular}

a. Dependent Variable: Kinerja Karyawan

Nilai error term (e) sebesar 0,926, dimana memiliki arti kinerja karyawan yang dipengaruhi oleh faktor luar dari kompensasi, motivasi dan kepuasan kerja. Oleh karena Standardized Coefficients Beta $=0,178$ dan Sig $\mathrm{t}=0,049<0,05$ maka dapat disimpulkan kompensasi berpengaruh positif pada kinerja karyawan. Oleh karena Standardized Coefficients Beta $=1,409$ dan Sig t $=0,008<$ 0,05 maka dapat disimpulkan motivasi berpengaruh positif pada kinerja karyawan. Oleh karena Standardized Coefficients Beta $=$
0,348 dan Sig $\mathrm{t}=0,000<0,05$ maka dapat disimpulkan kepuasan kerja berpengaruh positif pada kinerja karyawan. Oleh karena Standardized Coefficients Beta $=0,348$ dan Sig $\mathrm{t}=0,002<0,05$ maka dapat disimpulkan kepuasan kerja berpengaruh positif pada kinerja karyawan.

\section{SIMPULAN}

Berdasarkan hasil penelitian yang telah diuraikan, maka kesimpulan yang diperoleh 
adalah kompensasi mempunyai pengaruh positif terhadap kepuasan kerja PT. Bank Negara Indonesia (Tbk) Persero cabang batam. Hal ini berarti semakin sesuai kompensasi yang diberikan menurut kebutuhan hidupnya, maka kepuasan karyawan PT. Bank Negara Indonesia (Tbk) Persero cabang batam akan meningkat. Motivasi mempunyai pengaruh positif terhadap kepuasan kerja PT. Bank Negara Indonesia (Tbk) Persero cabang batam. Hal ini berarti, semakin tinggi motivasi karyawan kepada perusahaan maka mendorong karyawan untuk mendapatkan prestasi. Kepuasan kerja karyawan PT. Bank Negara Indonesia (Tbk) Persero cabang batam akan meningkat.

Kompensasi mempunyai pengaruh positif terhadap kinerja karyawan PT. Bank Negara Indonesia (Tbk) Persero cabang batam. Hal ini berarti kompensasi yang adil akan dapat meningkatkan kinerja karyawan. Motivasi mempunyai pengaruh positif dan signifikan terhadap kinerja karyawan PT. Bank Negara Indonesia (Tbk) Persero cabang batam. Hal ini berarti semakin termotivasi karyawan maka akan menciptakan hubungan yang baik antar karyawan PT. Bank Negara Indonesia (Tbk) Persero cabang batam akan meningkat. Kepuasan kerja memiliki pengaruh positif dan signifikan terhadap kinerja karyawan PT. Bank Negara Indonesia (Tbk) Persero cabang batam. Kepuasan yang tinggi akan meningkatkan kinerja karyawan.

\section{DAFTAR PUSTAKA}

Basuki, Andi. (2009). Pengaruh Gaya Kepemimpinan dan Pengalaman Kerja Terhadap KinerjaKaryawan PT. HAMUDHA PRIMA MEDIA BOYOLALI. Universitas Sebelas Maret. Surakarta.

BPFE, Universitas GajahMada, Yogyakarta.

Gunadi1, Irawan,A, Ratnasari,L Wibisono. C (2015) Kualitas Pelayanan Sebagai Variabel Intervening Antara Kompetensi Kepegawaian Dan Budaya Kerja Terhadap Kepuasan Kerja Mitra Di Pelayanan Terpadu Satu Pintu Badan Pengusaha Kawasan Perdagangan Bebas Dan Pelabuhan Bebas Batam. Fakultas Ekonomi Universitas Batam Jurusan
Manajemen Bisnis, Politeknik Negeri Batam. Batam

Handako, T. Hani. 2001. Manajemen Personalia dan Sumberdaya Manusia,

Hanggraeni, D (2012) Manajemen Sumber Daya Manusia. Penerbit Fakultas Ekonomi Universitas Indonesia. Cetaka ke - 1

Hasibuan, Melayu SP. (2012). Manajemen Sumber Daya Manusia. Edisi Revisi Cetakan Keenambelas. Jakarta : Bumi Aksara.

Hati,S.W, Brahmana,I (2016) Pengaruh Kompensasi Financial Terhadap Kinerja

Heidjrachman, Husna, H (2008) Manajemen Personalia. Cetakan ke Sebelas. BPFEYOGYAKARTA.

Karyawan Dengan Motivasi Kerja Sebagai Variabel Intervening Pada Kantor Pusat PT. Citra Buana Prakarsa. Prodi Administrasi Bisnis Terapan Politeknik Negeri Batam. Batam.

Murty Windy Aprilia., Hundiwinarsih Gunasti. 2012. Pengaruh kompensasi, motivasi dan komitmen organisasional terhadap kinerja karyawan bagian akuntansi (studi kasus pada perusahaan manufaktur di Surabaya). Jurnal The Indonesian Accounting Review, 2(2), pp: 215-228.

Musfiqon. (2012) Panduan Lengkap Metodologi Penelitian Pendidikan, Penerbit PT. Prestasi Pustakarya. Jakarta

Rachmawati, I.K. (2008) Manajemen Sumber Daya Manusia. Penerbit C.V ANDI OFFSET. Yogyakarta

Rivai, H.V., Sagala,E.J Manajemen Sumber Daya Manusia Untuk Perusahaan. Penerbit RajaGravindo Persada Cetakan ke-4. Jakarta

Riduwan. (2012). Cara menggunakan dan Memaknai Path Analisi (analisis jalur). (B. Alma, Ed.) (Cetakan Ke). Bandung: ALFABETA.

Sanusi, Anwar. (2011). Metode Penelitian Bisnis. SalembaEmpat. Jakarta

Sugiyono.(2012). Metode Penelitian Kuantitatif, Kualitatif, dan $R \& D$. Penerbit Alfabeta, Bandung.

Sulistyo Budi Utomo. 2010. Pengaruh Motivasi Dan Kepuasan Kerja Terhadap Kinerja Karyawan CV Berkat Cipta Karya Nusantara Surabaya. Jurnal Akuntansi, Manajemen Bisnis Dan 
Sektor Publik (JAMBSP) 6(3), pp:376393.

Susanto,H dan Aisiyah N (2010) Analisis Pengaruh Kepemimpinan Dan Budaya Kerja Dengan Motivasi Sebagai Variabel Intervening Terhadap Kinerja Karyawan. Magistra No. 74 Th.

Suwandi, $\quad$ E.D.D 2014

PengaruhKualitasPelayanan Kualitas PelayananTerhadapa LoyalitasNasabah Dengan Kepuasan Sebagai Variabel Intervening. Magister Sains Manajemen Unversitas Palangka Raya

Wibowo, AgungEdy. (2012). Aplikasi Praktis SPSS DalamPenelitian.Penerbit Gaya Media.Yogyakarta.

Wijayanto, D.(2012) Pengantar Manajemen . Penerbit PT.GramediaPustaka. Anggota IKAPI, Jakarta.

Yani, M. (2012).Manajemen Sumber Daya Manusia. Edisi Asli. Mitra Wacana Media. Jakarta 